\title{
Legislators' Patterns of Cooperation
}

\author{
Osnat Akirav $^{1}$ \\ ${ }^{1}$ Department of Political Science, The Western Galilee College, Akko, Israel \\ Correspondence: Osnat Akirav, Department of Political Science, The Western Galilee College, Akko, Israel.
}

Received: December 5, 2016

Accepted: January 10, $2017 \quad$ Available online: January 14, 2017

doi:10.11114/ijsss.v5i2.2148

URL: http://dx.doi.org/10.11114/ijsss.v5i2.2148

\begin{abstract}
This study attempts to identify the patterns of cooperation between legislators. We argue that if legislators decide to cooperate, they prefer to do so first with their colleagues who share similar affiliations and then across affiliations. In order to examine this hypothesis, we devised a unique cooperation scale and tested it using a sample of the private member bills that were initiated in the $18^{\text {th }}$ Knesset (Israel's parliament) between 2009 and 2013. We then looked at each bill with regard to its initiators and co-sponsors to see if they were members of the same party, members of the opposition or coalition, or members of a minority group. Based on the quantitative analysis, we found that of all of the factors, only being a minority was significant. Based on the qualitative analysis, we determined that intra-party cooperation does exist. In three parties - Hadash, Meretz and Israel Beitenu -- legislators tended to cooperate with each other. Finally, with regard to inter-party cooperation, Jewish and Arab MKs tended to cooperate, and Russian Jewish legislators tended to cooperate regardless of party affiliation. Our study is innovative in its creation of a cooperation scale that can be used in other legislatures and that is based on measures of co-sponsorship instead of analyses of dyadic or social networks used in previous studies.
\end{abstract}

Keywords: inter-party cooperation, intra-party cooperation, cooperation scale, co-sponsors, legislation, legislators' behavior

\section{Introduction}

Legislators in modern democracies tend to cooperate with each other when they have common goals (Matthews, 1960; Fenno, 1973; Mayhew, 1974). The question this study asks is that what is the pattern of this cooperation? What are the incentives to do so, compared to the costs of cooperation? Furthermore, if such cooperation exists, does it exist between legislators of different parties, between those who are minority members and those who are in the majority, or between those who are members of the coalition and the opposition and those who are members of the same party? To address these questions, we developed a preliminary cooperation scale based on the different patterns we found in initiating and co-sponsoring bills.

Given that sharing a position is one of the major predictors for co-sponsoring a bill (Cox \& McCubbins, 1993; Crisp, Kanthak, \& Leijonhufvud, 2004), we maintain that legislators will first cooperate with the groups with whom they share an affiliation in what we call intra-party cooperation. However, when the subject of the legislation is important to them, they will cooperate across affiliations in what we term inter-party cooperation or cooperation within parliament.

The research has two goals. First, we seek to expand the discussion about the use of bill sponsorship to democracies with parliamentarian regimes such as those in Europe and Israel, because most previous studies concentrate on the US Congress. Second, we want to consider cooperation from a standpoint different from that of existing studies and then suggest an addition point of view.

\subsection{Ambitions and Tendency to Cooperate}

Legislative scholars generally agree that the job of legislators is multifaceted and revolves around three main roles: legislation, oversight and representation. Hence, they are multi-dimensional actors (Fenno, 1978; Searing, 1994; Strøm, 1997; Mayhew, 2000; Blomgren \& Rozenberg, 2012). Furthermore, legislators act in two arenas within parliament--formal and informal. Formal activity refers to those actions based on the procedures of the legislatures, and informal activity involves actions that are not based on written procedures. We will concentrate on one specific formal parliamentary tool and one that is considered significant - legislation.

Legislators have three roles--legislation, representation and oversight. In addition, according to Strøm (1997), their 
goals include being re-selected to run for office, being re-elected, obtaining a party office or receiving a legislative office. In order to achieve their goals and play their roles, do they cooperate with each other? If so, what are their patterns of cooperation? Finally, what are the characteristics of the legislators who cooperate with others as opposed to those who do not?

Based on in-depth interviews we conducted with a sample of members of the Israeli Knesset (MKs), we found that legislators' preferences and attitudes toward cooperation are a major factor in their decision to cooperate with other legislators. Nevertheless, they do not operate alone or function without constraints, one of which is the institutional rules of the legislature (Searing, 1994; Strøm, 1997). Schlesinger's (1966) ambition theory posits that legislators are rational actors who make political decisions consistent with their political ambitions that maximize the probability of realizing their goals. Progressive ambition, as defined by Schlesinger, is about a long-term career in steadily improving positions. Furthermore, it is the most common form of ambition among politicians (Herrick \& Moore, 1993; Rohde, 1979; Borchert, 2011), but whether they act on it depends on their calculus--is it worthwhile trying to run for a higher office? (Rohde, 1979). Legislators who do engage in progressive ambition tend to be legislatively active in terms of introducing bills, floor activity and committee work (Herrick \& Moore, 1993; Victor, 2005). They are more sensitive to changes in public opinion, suggesting a desire to appeal to a broader constituency and to various media outlets in addition to relevant state and national party leaders (Axelrod, 1984; Arnold, 1990; Maestas, 2008). If legislator $i$ is progressively ambitious and legislator $j$ is also progressively ambitious, they have many opportunities to engage in mutually rewarding activities and are therefore more likely to cooperate. Axelrod (1984) claimed that these mutually rewarding actions have led to the creation of an elaborate set of norms in the Senate. They include vote trading, but also extend to many types of mutually rewarding behavior.

Empirical work following Axelrod's model has helped establish the prevalence of cooperation based on reciprocity (Axelrod \& Dion, 1988; Victor, 2005). Therefore, we can see that scholars agree that legislators are ambitious and engage in their formal and informal parliamentary activities to achieve progressively higher positions. The question is whether in order to improve their position they will cooperate and if so, in what kind of cooperation will they engage? In sum, based on the ambition theory, ambition is a personality construct and is, therefore, evident in an individual's behavior. Legislators as rational actors need to decide whether to try to realize their ambitions by determining whether it is worthwhile running for higher office. Thus, we argue that a legislator's decision to cooperate with his/her colleagues depends on personal preferences and his/her attitude towards cooperation. Based on the in-depth interviews we conducted, the legislators all claim that they believe in cooperating with one another. However, our statistical analysis of their patterns of cooperation reveals that there is a gap between these statements of support for cooperation and actual practice.

Ambitious legislators do not function in a vacuum. The immediate organization relevant to the legislators is the party, whose importance in parliamentary life has been investigated extensively (Krehbiel, 1993; Cox \& McCubbins, 2005; Jenkins, Crespin, \& Carson, 2005; Treul, 2009). These studies demonstrate that progressively ambitious legislators in the US Senate are more loyal to the party than their colleagues who never had the desire for higher office (Treul, 2009). Furthermore, the party affects the behavior of its members (Krehbiel, 1993; Cox \& McCubbins, 2005; Jenkins et al., 2005). It plays a significant role in legislators' careers in various ways. First, legislators seek to join together with those with whom they share a similar affiliation. Second, political parties provide legislators with a brand name to ensure that the typical problems associated with providing a public good are overcome, and that legislative actions can foster their reputations. Parties are created primarily to reap electoral gains (Smith \& Gamm, 2001; Evans \& Oleszek, 2002). The cartel party model describes a strong and cohesive party that votes as a bloc (Cox \& McCubbins, 2005). In the last decade there has been a new group of studies referring to the party as a network for its members (Fowler, 2006a; Kirkland \& Gross, 2014; Parigi \& Sartori, 2014). The party has an internal structure made up of a network of legislators informed by external social divisions and held together by the common goal of being re-elected (Parigi \& Sartori, 2014).

In the current study we will use the term inter-party cooperation to describe cooperation between at least two legislators from different parties. Previous scholars have called it bipartisan behavior (Harbridge, 2010; Louwerse \& Otjes, 2015). It can be true in a party system with two major parties such as the US Congress (Harbridge, 2010), but in a multi-party system such as those in Western European countries it fails to describe the real picture.

Harbridge (2010) suggested the notion of the cut-point to define the co-sponsors of bipartisan bills. If twenty percent or more of the co-sponsors are from the party opposite the party of the bill's sponsor, it can be considered bipartisan. This concept of the cut-point can be relevant to the bipartisan party system in the US Congress, but it is not relevant to multi-party systems in parliamentarian democracies such as Europe and Israel. Furthermore, from our perspective even one representative from another party as a co-sponsor qualifies as cooperation. The second term we use is intra-party cooperation to describe cooperation between at least two legislators from the same party. This term accords with 
previous studies that used the term partisan behavior.

Given that party matters, there are two puzzles we need to address regarding cooperation. First, is intra-party cooperation the best way to pass legislation? Wouldn't inter-party cooperation be a better strategy, because it would demonstrate broad support among several parties? Previous studies provide inconclusive answers to these questions. In some cases, intra-party cooperation is more significant. US Congress people engage in more bipartisanship when the party is unpopular than when it is popular (Harbridge, 2010). Similarly, Dutch parliamentarians play their partisan roles within specialized policy fields (Louwerse \& Otjes, 2015). However, in other cases inter-party cooperation is more significant (Briatee, 2016).

The second puzzle is why inter-party cooperation is even considered, because it works against party cohesion, making it disadvantageous to the party. Cohesion has been defined as "the extent to which . . group members can be observed to work together for the group's goals" (Ozbudun, 1970, 305). This definition accords with partisan or inter-party cooperation. Nevertheless, scholars have also argued that, "Cohesion and discipline matter in the daily running of parliaments. The maintenance of a cohesive voting bloc inside a legislative body is a crucially important feature of parliamentary life" (Bowler, Farrell, \& Katz, 1999, 3). Therefore, inter-party cooperation implies that party cohesion will be damaged.

We contest this claim and argue that inter-party cooperation can actually be beneficial for the party. For example, if the issue is consensual, the likelihood of inter-party cooperation will increase. The legislators who are part of the inter-party cooperation can encourage their party members to join them, hence unifying the party on a specific consensual issue. Rahat (2007) found that cohesion in the Israeli parliament was relatively high on issues directly linked to the survival and everyday functioning of the government. There was a medium degree of cohesion regarding issues that defined the parties' identities and possibility of remaining in the coalition. Finally, party cohesion was at its lowest when the vote was on constitutional issues.

To determine what patterns of cooperation prevail in the Israeli Knesset, we created a cooperation scale based on the literature about co-sponsorship.

\subsection{Legislation and Co-sponsorship}

Legislation is considered one of the most important roles of legislators. It is also regarded as one of the most constrained parliamentary tools, one that demands a high price in terms of resources from legislators throughout the entire process of legislation (Olson, 1994; Wawro, 2000; Cox \& McCubbins, 2005; Garand \& Burke, 2006). Like most of these previous studies, this paper concentrates on the initiation of legislation and focuses on the co-sponsorship of legislation (Koger, 2003; Fowler 2006a; Harbridge, 2010; Louwerse \& Otjes, 2015) in order to determine the cooperation patterns of the members of the Israeli parliament.

Some may argue that bill sponsorship seems to be an irrational act of otherwise rational legislators. However, the sponsorship of bills has become a very important part of the legislative process and exists in legislatures worldwide. It is unique because sponsorship is not about voting on legislation. Members of Congress invest a great deal of time convincing their colleagues to sponsor their legislation (Wilson \& Young, 1997; Koger, 2003; Fowler 2006a). Even though sponsoring bills has no formal effect on the legislative process, the sponsorship enables legislators to take a position (Campbell, 1982; Koger, 2003; Woon, 2008; Rocca \& Gordon, 2010) and can have policy implications (e.g., Kessler \& Krehbiel, 1996; Koger, 2003; Rocca \& Sanchez, 2008). The sponsorship of bills gives political leaders low cost information about the political gain they can achieve from legislation (Koger, 2003). Alternatively, legislators can use the list of a bill's co-sponsors to assess its level of support, ideological stance and endorsement by reputable experts (Wilson \& Young, 1997).

Legislators have used both roll call and co-sponsorship data to determine what policies the public favors (Aleman, Calvo, Jones, \& Kaplan, 2009). Furthermore, using sponsorship to measure minority activity helps us see what positions they are taking (Schiller, 1995; Koger, 2003) and what kinds of policies they favor (Kessler \& Krehbiel, 1996; Talbert \& Potoski, 2002). The strength of sponsorship is meaningful for the minority, so it is interesting to observe how they use it. Nevertheless, a recent study about minorities in the US Congress found that they use sponsorship less often than their non-minority colleagues (Rocca \& Sanchez, 2008). Thus, bill sponsorship is not an irrational act. It provides extensive information about the behavior of legislators that is non-legislative. Since the basic behavior in co-sponsorship is that legislator $i$ will cooperate with legislator $j$, some scholars study this type of relationship using three theoretical approaches: network analysis theory, bipartisan theory and signaling theory (Wilson \& Young, 1997; Sunnafrank \& Ramirez, 2004; Fowler, 2006a, 2006b; Harbridge, 2010; Peress, 2013; Louwerse \& Otjes, 2015; Briatee, 2016). Furthermore, both theoretically and empirically there are three levels of analysis of co-sponsorship: the individual level, the dyadic level, and the group level. 
The individual level accords with the signaling theory, which discusses when an individual legislator decides to co-sponsor a bill. Hence, the signaling theory is useful for describing behavior when two parties $(P i, P j)$ or two legislators $(i, j)$ have access to different information or take different positions on an issue. Typically, one party or legislator, the sender, must choose whether and how to communicate (or signal) that information or position, and the other party or legislator, the receiver, must choose how to interpret the signal. Co-sponsoring a bill can be considered providing information about a legislator's position on a particular topic. Therefore, other legislators can decide whether to join him/her. Furthermore, before voting on a bill, legislators can see the number of co-sponsors on a specific bill and the other legislators who sponsored it. According to the signaling theory, such information allows legislators to decide whether they want to vote yes or no on the bill. For example, Peress (2013) created a model that assumed that legislators use co-sponsorship as a signaling mechanism.

The dyadic level is about legislator $i$ cooperating with legislator $j$, indicating reciprocity of political support among pairs of legislators. The dyadic level accords with the bipartisan theory at the most basic level of just two legislators cooperating with each other. The group level is all about network analysis, how more than one pair of legislators cooperates with each other. Fowler (2006a, 2006b) called it connectedness, while Briatte (2016) described multi-levels of partisanship based on the propensity of MPs to co-sponsor bills within and across party lines.

We base our analysis on the individual level and the signaling theory but diverge from previous studies that use the individual level by focusing on a bill and its composition of initiators and co-sponsors. We conducted our study in Israel to expand the research in this field, which to date has concentrated mostly on the US Congress (Kessler \& Krehbiel, 1996; Talbert \& Potoski, 2002; Koger, 2003; Fowler, 2006a, 2006b; Harbridge, 2010), the Netherlands (Louwerse \& Otjes, 2015) and Argentina (Aleman et al., 2009).

Despite the fact that the Israeli parliament is structured differently than the other parliamentary systems that have been investigated in its candidate selection method and electoral system, it is interesting to note that Israeli legislators use co-sponsoring as extensively as US Congress people. Therefore, we feel justified in using Israel as the basis for the creation of our cooperation scale and feel confident that once validated, it can be used to assess cooperation in other parliaments worldwide.

\subsection{Preliminary Cooperation Scale}

The development of the preliminary cooperation scale is based on both the interviews we conducted with MKs and the literature presented previously. Co-sponsoring a bill simply means that the initiator asks another MK to add his/her name to the bill. Doing so requires almost no investment of time on the part of the co-sponsoring MK, other than to ascertain who else is signing on to the bill and to calculate the costs and benefits of doing so. There are times when some of the co-sponsors suggest other MKs as co-sponsors too. On the other hand, to initiate a bill with several MKs and ask for co-sponsorship from several MKs requires much more time, Hence, in our scale the degree of cooperation increases when both sides need to sit and talk about the bill that is going to be presented.

There are six categories of cooperation strategies in our scale: non-initiator (the MK does not bring bills to the table), individualistic (non-cooperative legislator who works alone) (the MK proposes bills alone), little cooperation (the MK sponsors bills but does not initiate them), medium cooperation (the MK initiates bills with one or more colleagues without looking for sponsors for them), extensive cooperation (the MK initiates bills alone with one or more sponsors) and very extensive cooperation (two or more MKs initiate bills with one or more sponsors). Based on the MKs' patterns of cooperative behavior, we graded them as follows: 1-non-cooperative, 2- individualistic, 3- little cooperation, 4-medium cooperation, 5- extensive cooperation and 6- very extensive cooperation.

Our unit of analysis, which differs from previous studies, is the bill and the amount of time the legislator or legislators invested in it. We will also speculate on some possible explanations for variations in the degree of cooperation.

\subsection{Does Affiliation Matter?}

Scholars suggest a wide range of variables to explain parliamentary behavior. The current study will concentrate on two: being a minority and membership in the coalition or opposition (in some legislatures, being part of the majority party).

First, we need to clarify and distinguish the two variables based on the Israeli context. By minorities we mean Arab MKs. The majority refers to Jewish MKs. Israel has a coalition government, so at any given time some parties are part of the coalition and others are in the opposition. Since the establishment of the State of Israel, the Arab political parties have been in the opposition.

\section{Minority Membership}

Given that those in the minority in legislatures are excluded from the decision-making process, they tend to use tools that have fewer restrictions and are more evident to the public (Hamm, Harmel, \& Thompson, 1983; Koger, 2003; 
Rocca, 2007). Most of the research regarding minorities in parliaments concentrates on African-American MCs (Mansbridge, 1999; Cobb \& Jenkins, 2001; Tate, 2003) and has found that African-American legislators are less successful in several state legislatures (Bratton \& Haynia, 1999). Other studies have examined Hispanic MCs (e.g., Hero \& Tolbert, 1995; Lublin, 1997), minority legislators in the UK (Saalfeld, 2011) and the Arab minority in the Israeli parliament (Akirav, 2014). One of the reasons for minority legislators' lack of success is that policies reflecting the preferences of the average voter are most likely to pass the House (Krehbiel, 1991; Wiseman \& Wright, 2008). Given that minority legislators are institutionally disadvantaged (Morris, 2001; Rocca, 2007), we would expect them to cooperate with each other extensively, especially because legislation is considered the most difficult parliamentary goal to accomplish.

However, in Israel majority-minority relations has a unique context in that Israel is the only country in the Middle East in which Arabs are a minority. At the same time, the Jewish majority in Israel is a minority in the Middle East, and the state is surrounded by hostile Arab countries. Hence, the Arab minority in Israel differs from the majority both in terms of nationality and religion, in addition to its connection to the global Arab world.

Given this discussion about the role of being a minority, our first hypothesis states that:

$\mathrm{H} 1$ : Arab MKs will tend to cooperate with each other more than with Jewish MKs.

Coalition/Opposition Membership

Membership in the majority party is the dominant explanation for legislative effectiveness (Frantzich, 1979; Meyer, 1980; Moore \& Thomas, 1991; Weissert, 1991; Aldrich, 1995; Cox \& Magar, 1999; Krehbiel, 1999; Anderson, Box-Steffensmeier, \& Sinclair-Chapman, 2003; Miquel \& Snyder, 2006; Hasecke \& Mycoff, 2007; Cox \& Terry, 2008). The power of the coalition legislators or majority party legislators allows them to cooperate with other legislators across affiliations, especially because they have the power to pass legislation.

Given this discussion about the role of coalition/opposition membership, we expect that:

$\mathrm{H} 2$ : Legislators from the coalition will tend to cooperate with each other to the same extent as legislators from the opposition.

\section{The Israeli Context}

Israel has a unicameral parliament whose members are elected by a closed-list system of proportional representation with the entire country serving as one constituency. Its political system has been described as a hybrid, combining electoral rules, a fragmented party system and bipolar competition (Ottolenghi, 2004; Rahat \& Hazan, 2005).

In the first 30 years of its history, Israeli politics was dominated by the Mapai Party (later the Labor Party), which, although it never won an outright majority, always formed the basis of the government. After Labor's defeat in 1977, and especially during the 1980 s, the Israeli party system fragmented and chronic policy stalemates developed. Two successive reforms sought to remedy this problem. The first, passed in 1992, introduced the direct election of the prime minister. After the failure of this reform to address the problems it was intended to fix, in 2001 the Knesset restored most of the old system, with the important addition of a constructive vote of no confidence (to remove a sitting prime minister, at least $61 \mathrm{MKs}$ must vote for a specific alternative candidate).

In Israel each party can choose the way it selects its candidates. Currently, there are three dominant practices: a closed primary in which all party members vote, a party caucus in which a few hundred party members choose the candidates, and an appointed committee in which a small select group of leaders choose the candidates. Thus, the candidates do not represent a geographically defined constituency, but may feel that they represent the interests of a particular group. For example, Yahadut Hatora sees itself as speaking for the ultra-Orthodox community. The Arab parties (in the last election they created a joint list of the four Arab parties) also have their specific audiences that might be considered constituencies.

We test our cooperation scale using data from the 18th Knesset when Israel's 32nd government - Benjamin Netanyahu's second - was sworn in on 31 March 2009. Since the establishment of Israel, it was the third government and the first one in the last 30 years that lasted the full years of the Knesset's term. Netanyahu's government was backed by four distinct coalitions during his time in office. The first coalition consisted of Likud (27 seats), the Russian immigrant party Israel Baaliya (15 seats), the Sephardic religious party Shas (11 seats), the Labor Party (13 seats), the National Religious Party ( 3 seats), and the ultra-Orthodox Jewish party Yahadut Hatora (5 seats), for a total of 74 out of the Knesset's 120 seats. The second coalition was established when the Labor Party withdrew from the government, but five of its members established a new party called Haaztmaut, which remained in the government, creating a coalition of 66 out of 120 seats. The third coalition was the shortest one, lasting between 8 May 2012 and 7 July 2012 when Kadima, the largest party in the Knesset with 28 seats, joined the government and established a coalition of 94 seats out 
of 120. The fourth coalition was created when Kadima withdrew from the coalition, leaving it with 66 members.

Based on Morgenstern, Negri, and Perez-Linan (2008), we calculated the opposition partisan unity (the ratio between the number of seats of the largest opposition party and the total seats the opposition has). For the first coalition, that number was 0.6 , for the second -0.51 , for the third -0.15 and for the fourth -0.48 . Generally, when there is a large opposition, we would expect little cooperation between it and the coalition unless the topic of the bill promotes cooperation.

\section{Methodology}

In order to test the research hypotheses, we gathered data from the $18^{\text {th }}$ Knesset (February 2009 - February 2013 ). Based on the Rules of Procedure, every MK (except ministers and deputy ministers) is entitled to co-sponsor bills without any restrictions. Since February 2009, 4,593 private member bills have been presented in the Knesset, and $2,585(56 \%)$ of them were initiated by one MK. Hence, our database includes the other 2,008 (44\%) bills that involved some form of cooperation: two or more initiators without co-sponsors, one initiator with one or more co-sponsors, and two or more initiators with one or more co-sponsors. Using a probability layer sample in which every year in the Knesset's term (four years and two months) was considered a layer, we sampled 259 of the 2,008 bills in the database, resulting in 65 bills involving cooperation. For each bill, we gathered the following information: who initiated the bill, who sponsored it, the characteristics of the initiators and the sponsors (minority membership and coalition/opposition), the subject of the bill and whether it passed.

During 2012, we also conducted in-depth interviews with a sample of MKs (15 out of 85 who were not ministers or deputy ministers) to hear their perspectives about the cooperation strategies they use in legislation. We sent e-mails to all of the $85 \mathrm{MKs}$, asking them to interview them. Fifteen agreed and answered open-ended questions such as: "What is you perception regarding cooperating with other MKs?" "Do you cooperate with other MKs?" "How do you decide whether or not to cooperate with them?" Two assistants coded the content of the interviews each separately. We then conducted an inter-coder reliability test to assess their analysis. The results were similar with only a few insignificant differences.

We also used Briatte's (2016) dataset of 150 bill co-sponsorship networks that covers 27 parliamentary chambers from 19 European countries, plus Israel. The data show the extent of partisanship expressed by MPs through their propensity to co-sponsor bills within and across party lines in several different parliamentary systems. From this dataset we looked at seven Western European countries (Austria, Belgium, Finland, Ireland, Norway, Italy and France) to compare to Israel. We chose these countries because they all have a multi-party, parliamentary political system (except France with a semi-presidential political system) and are established democracies with data from the end of the 1980 s until 2016.

Thus, our research is based on a mix of qualitative and quantitative research methods. First, we present data from Western European countries collected by Briatte (2016) to compare to Israel. Second, we analyze the number and composition of the cooperation strategies and the content of the Israeli bills. Then, we review the content of the interviews and the content of the bills that passed.

\section{Findings and Discussion}

\subsection{Strategic Alliances - How Do They Work?}

The number of co-sponsored bills in Briatte's dataset ranges from 8 (Ireland) to 2,096 (Italy). The average is 425, the median 276 and the standard deviation is 494. Clearly, there are major differences in how representatives use the option to co-sponsor bills. However, we can see that the numbers are high and seem to be increasing over time.

We conducted an ANOVA test between the different countries $(\mathrm{F}=48.63$, Sig=0.00) and found differences between the countries in the way representatives use co-sponsorship. For example, the members of the Italian parliament co-sponsor bills more often than all the other countries. Israel ranks second after Italy in this regard. In contrast, the members of the Irish parliament engage in co-sponsorship much less frequently than representatives in other countries. France, Norway, Austria, Belgium, and Finland have a mixed pattern

Briatte provides graphs that describe the networks involved in co-sponsorship. Italy and France are the countries with the most intensive intra-party cooperation. The clusters for each party are cohesive, with only a few ties to other parties. Ireland has a similar pattern of intra-party cooperation but makes limited use of co-sponsorship (9 to 12 bills for each term). In Finland, Norway and Belgium there is an intra-party pattern with moderate inter-party cooperation. Israel and Austria have a mixed pattern, involving both inter-party and intra-party cooperation. Israel and some of the Western European countries that were examined behave similarly to the US Congress in their use of co-sponsoring bills.

With regard to Israel, from the beginning of the $18^{\text {th }}$ Knesset in February 2009 until its end in February 2013, Israeli MKs initiated 4,593 private bills, but just 272 became law (6\% of the total). The average rate of passage of private bills 
in the Knesset is around 10\%. Here we can see an increase in the number of the bills initiated compared to previous Knesset terms, but a decrease in the number of bills that passed. In the same Knesset term, the government brought 341 bills to the table and passed 306 (90\% of the total), matching the rate of previous governments. Some might say that such numbers indicate high productivity on the part of the representatives, while other will argue that the actual measurement that matters is the number of bills that passed (Matthews, 1960; Frantzich, 1979; Moore \& Thomas, 1991; Wawro, 2000; Anderson et al., 2003; Garand \& Burke, 2006; Cox \& Terry, 2008). The current research examines both the initiation and the passage of the legislation (with and without co-sponsorship) in terms of their number and content, with a particular focus on the cooperation strategies used.

Table 1. Initiating and sponsoring private bills by cooperation strategies

\begin{tabular}{lll}
\hline Initiators and co-sponsors & $\begin{array}{l}\text { More than one initiator, without } \\
\text { sponsors }\end{array}$ & \\
\hline 233 & 26 & $\begin{array}{l}\text { Number of private bills } \\
\text { Percentage } \\
\text { of the total (n=259) }\end{array}$ \\
$90 \%$ & $10 \%$ & \begin{tabular}{l} 
of \\
\hline
\end{tabular}
\end{tabular}

Table 1 shows that most of the cooperation strategies involved initiating and co-sponsoring bills $-90 \%$. Only $10 \%$ of the bills were co-initiated without sponsors at all. Based on the interviews we conducted with MKs, we can say that they see cooperation as a way of life, not just in the legislative arena, but also in all of the other parliamentary activities in which they are involved. As Nowak (2006) claimed, cooperation means that people forgo some of their selfishness to help one another.

Looking at the data, we maintain that a significant number of MKs (excluding ministers and deputy ministers) prefer to cooperate with their colleagues. Furthermore, the preferred cooperation strategy is initiating and co-sponsoring bills. The results strengthen previous studies regarding the use of sponsorship (e.g., Campbell, 1982; Kessler \& Krehbiel, 1996; Koger, 2003; Fowler, 2006a; Rocca \& Sanchez, 2008; Woon, 2008).

The cooperative strategies model posits two situations in which legislators will cooperate. First, MKs will cooperate with the groups with whom they share an affiliation. Second, when the subject of the legislation is important to them, they will cooperate across affiliations. In order to examine these two cooperation strategies we coded each bill regarding the type of cooperation it entailed: 1 for intra-party and 2 for between parties. Furthermore, we looked at each strategy with regard to whether it involved cross opposition/coalition cooperation or within coalition and within opposition cooperation. Table 2 presents the distribution of the bills with regard to opposition intra-party cooperation and coalition intra-party cooperation.

Table 2. Intra-party cooperation

\begin{tabular}{|c|c|c|c|c|}
\hline $\begin{array}{ll}\text { Coalition } & \text { intra-party } \\
\text { cooperation } & \end{array}$ & \multicolumn{4}{|c|}{ Opposition intra-party cooperation } \\
\hline The party & Number of bills & The party & & Number of bills \\
\hline Israel Beiteinu & $52(93 \%)$ & Hadash & & $134(76 \%)$ \\
\hline United Torah Judaism & $3(5.4 \%)$ & Meretz & & $30(17 \%)$ \\
\hline Labor & $1(1.6 \%)$ & $\begin{array}{l}\text { National } \\
\text { Assembly }\end{array}$ & Democratic & $6(3.4 \%)$ \\
\hline & & Ra'am-Ta'al & & $5(2.9 \%)$ \\
\hline & & Kadima & & $1(0.7 \%)$ \\
\hline Total & 56 & Total & & 176 \\
\hline
\end{tabular}

Most of the intra-party cooperation was among opposition parties, which is not surprising for two reasons. First, such actions accord with the legislators' attitudes toward cooperating with their colleagues within the same parties. Second, the opposition, which is in a weaker position, must cooperate with other parties to pass legislation.

Analyzing the content of bills looking for cooperation strategies, we found several interesting patterns of behavior.

Cooperation in Arab National Minority Parties. In the $18^{\text {th }}$ Knesset, there were three Arab parties: Hadash, Ra'am-Ta'al and National Democratic Assembly. There were also other Arab MKs who were members of Jewish parties. The most cooperative party was Hadash, which had three Arab MKs and one Jewish MK. Its strategic pattern was to initiate and co-sponsor bills whenever possible. MK Dov Khenin initiated most of the bills, which were co-initiated or co-sponsored by his party colleagues. In his interview, MK Khenin said that for him it was natural to cooperate with his party colleagues, and when they needed his sponsorship, he was always supportive. Three other Arab MKs from Hadash--Mohammad Barakeh, Hana Sweid and Afu Agbaria-almost always co-sponsored the bills that their Jewish party colleague MK Khenin initiated. Most of their bills revolved around issues of everyday life such as social welfare, employment, education, and health care. In contrast, the National Democratic Assembly cooperates little, and Ra'am-Ta'al does not cooperate almost at all. 
Opposition Parties. Another party that cooperates extensively is Meretz, with its three MKs. Like Hadash, it offers cooperation of all kinds, with one MK initiating bills and the other two co-sponsoring it, or two initiators and one sponsor and so on. Like Hadash, there is one MK, Haim Oron, the head of the party, who initiates most of the bills. He offered the same explanation about cooperating with colleagues that MK Khenin did. Finally, like Hadash, Meretz is a small party and in the opposition. This finding seems to support one of the explanations in the literature for cooperation strategies. Disadvantaged MKs tend to stick together and struggle to overcome the constraints they face as small, opposition or minority parties (e.g., Morris, 2001; Rocca, 2007).

Coalition Parties. We also found similar cooperation strategies in a party that is part of the coalition called Israel Beiteinu. Given that some of its members are ministers and deputy ministers and hence cannot bring private bills to the floor, the rest of the party's members tend to cooperate both in the initiation and co-sponsorship of bills. Furthermore, one of its members is Druze (a minority Arab group) and cooperates extensively with his party colleagues.

The Likud party did not show evidence of the cooperation strategies we found in the parties mentioned above. There are several explanations for this finding. First, as one of the largest parties with 27 seats and the ruling party in the coalition, a significant number of its members are ministers, deputy ministers and chairs of committees. Therefore, with the exception of the last group, they cannot bring a private bill to the floor. Another explanation may be the lack of cohesion in the party, which is a result of individual MKs fighting for their re-election. In such a competitive environment, the MKs do not consider cooperation in legislation a tool for helping them get re-elected (e.g., Bowler et al., 1999; Heidar \& Koole, 2004; Hazan, 2006). We found similar behavior in Kadima, the largest party with 28 seats, which was in the opposition during the entire Knesset term. This party originally split from the Likud and then picked up additional members from other parties. Therefore, the explanation about the lack of cohesion in the party seems a reasonable one in this instance as well.

The data show that cooperation strategies in the Israeli parliament generally occur in parties that are part of the opposition. Is this the case as well when we examine cross-affiliation cooperation strategies?

\subsection{Cross-affiliation Cooperation Strategies}

Table 3 demonstrates the distribution of cooperation across coalition/opposition lines and cooperation within just the coalition or opposition.

Table 3. Cooperation between parties and opposition/coalition affiliation

\begin{tabular}{lll}
\hline $\begin{array}{l}\text { Between party cooperation and across } \\
\text { opposition/coalition lines }\end{array}$ & Between party cooperation & \\
\hline & Within the opposition & Within the coalition \\
$13(50 \%)$ & $4(15.4 \%)$ & $9(34.6 \%)$ \\
\hline
\end{tabular}

Half of the cooperation is across opposition/coalition affiliations, while among the other half, most occurs within the coalition and less within the opposition. Thus, legislators from the opposition tend to cooperate more within their party and less with other opposition parties. Just one party from the coalition - Israel Beiteinu - cooperates extensively within the party but initiated only three bills with legislators from the Likud (another party from the coalition).

Analyzing the patterns of initiating and co-sponsoring, we found two groups that used cross-affiliation cooperation strategies extensively and one that used them infrequently.

Minority Group Members. By minority group members, we mean Arab MKs. The most frequent pattern of cooperation we found is when Jewish MKs initiate a bill, and Arab MKs co-sponsor it. The literature indicates that using sponsorship to measure minority activity reveals their position taking (Schiller, 1995; Koger, 2003) and what kinds of policies they favor (Kessler \& Krehbiel, 1996; Talbert \& Potoski, 2002).

In the $18^{\text {th }}$ Knesset, the dominance of the Jewish majority is significant. The Arab MKs adopted a subordinate position in order to promote their agenda. Given the situation, this was a realistic strategy. The second most frequent pattern of cooperation is when, once again, the Jewish MKs initiate a bill, but Jewish MKs join the Arab MKs in co-sponsoring it. In this case the Jewish majority still plays a significant role in the cooperation pattern.

The third most frequent pattern marks a shift in the cooperation pattern. Here Arab MKs initiate the bill, which is co-sponsored by both Jewish MKs and Arab MKs. In this cooperation pattern, the minority is dominant, and the majority is subordinate. These data are consistent with the literature detailing how minorities use co-sponsorship to take a position and define their policy. The fourth most frequent pattern is one in which Arab MKs and Jewish MKs initiate the legislation together without any kind of co-sponsorship. The fact that majority members and minority members sit together and invest time in order to create a shared bill is an important step toward cross-national legislative cooperation.

From the interviews we conducted with Arab MKs, they indicated that not only do they not rule out cooperation with 
Jewish MKs, but they also considered it an excellent means of promoting their agenda. Advancing their policies would usually be impossible if they relied solely on the support of the Arab MKs. The Arab MKs we interviewed noted that about $80 \%$ of the issues discussed in the Knesset are not controversial. They are social issues and therefore are relevant to all citizens of Israel regardless of their gender, nationality, religion or other affiliations. It is interesting to see the cooperation strategies and the serious work that is invested in the legislation that transcends the ideological disagreements between the Arab MKs and the Jewish MKs.

A closer examination of those who initiate and co-sponsor bills reveals several other patterns. Arab MK Hamed Amar initiates and usually co-sponsors bills with his party colleague from Israel Beiteinu (a right-wing Jewish party). Jewish MK Dov Khenin initiates and co-sponsors bills extensively with three of his party Arab MKs colleague (Hadash is a left-wing party with mainly Arab members and one Jewish MK). Arab MK Ahmad Tibi cooperates extensively with Jewish MKs, mainly on health care issues, regardless of their party affiliation or left-wing or right-wing stance. MK Tibi also co-sponsors Jewish MKs' bills. Majalli Wahabi, a Druze MK from the centrist Kadima Party, co-sponsors many bills initiated by Jewish MKs. Finally, while it is true that most of the cooperation is between Jewish MKs and Arab MKs from the left wing, there is also cooperation with Jewish MKs from the right wing as well.

What do these patterns say about cross-national cooperation strategies? First, it is win-win situation to cooperate cross-nationally. The Arab MKs gain the ability to set their agenda, which focuses on social issues, while Jewish MKs collect more votes to support their social initiatives. Second, we can see that as the majority, the Jewish MKs use such cooperation to set their agenda. Third, the Arab MKs need to choose between pride and realism. A realistic approach can bring about legislative success. Nevertheless, some of the Arab MKs interviewed chose to refrain from cross-national cooperation and were willing to pay the price of legislative failure. Fourth, most of the subjects on the Knesset agenda are not controversial. Indeed, in most cases, cooperation is the standard mode of operation in the Knesset

Russian Jewish Immigrants. MKs who immigrated to Israel from the former Soviet Union tend to cooperate on bills that are relevant to the Russian immigrants in Israel. Note that these MKs are from different parties and cross other affiliations.

Gender and Seniority. At first glance, there seems to be little cross-affiliation cooperation on the basis of gender or seniority. However, in the interviews, female MKs indicated that they do engage in such cross-affiliation cooperation when it comes to gender issues. Support for this statement comes from the protocols of the Committee on the Status of Women, which indicate cross-affiliation cooperation when it comes to gender issues.

\subsection{The Characteristics of the Cooperation}

After creating the scale and inputting our data into it, we looked at two factors that might explain the differences in cooperative strategies: being a minority member and membership in the coalition or opposition. Of the two factors, only being a minority member was significant $\left(\chi^{2}=4.035, \mathrm{Sig}=0.039\right)$. Arab MKs tend to cooperate more than Jewish MKs. We also identified this pattern in the content analysis of the bills. This finding strengthens previous studies regarding minority activity in legislatures (e.g., Schiller, 1995; Kessler \& Krehbiel, 1996; Talbert \& Potoski, 2002; Koger, 2003).

Being a member of the coalition or the opposition was not significant. This lack of significance is surprising given the results of previous studies. Perhaps it is because the sample is not big enough and does not reflect the entire picture. A second alternative explanation is based on the ambition theory - legislators prefer to act alone or when they do cooperate, it is an ad hoc decision rather than being based on the similarity of affiliation. A third alternative explanation is that due to changes in the Israeli political system, the power of the party leader and candidate selection methods, parliamentary activity has little effect on being re-selected to run for office, being re-elected or achieving higher office (Akirav, 2013). Therefore, co-sponsoring and passing legislation are less attractive endeavors than in other political systems.

\section{Conclusion}

MKs are rational actors, so they decide when it is best for them to cooperate. If they choose to cooperate with their colleagues, in accordance with the ambition theory, they do so to achieve the goals they want for their voters and for themselves. Furthermore, their first preference is to cooperate with their colleagues from the same affiliation, usually their own party. However, they will cooperate across affiliations on issues that are significant to them. Such preferences support the ambition theory, which argues that legislators will cooperate with others whom they trust only if the potential gains are greater than the potential losses (Axelrod \& Hamilton, 1981; Maynard, 1982; Axelrod, 1984; Chaudburi, Sopher, \& Strand, 2002). In addition, MKs will cooperate when they believe it will help them realize their ambition to be re-selected to run for office, re-elected or obtain a higher position (Schlesinger, 1966; Rohde, 1979; Herrick \& Moore, 1993; Francis \& Lawrence, 1996; Victor, 2005; Treul, 2009).

Consistent with this view and based mainly on the qualitative analysis, we also found that MKs cooperate primarily 
within their affiliations and less often across affiliations. Finally, there are some MKs who do not cooperate with others, having decided rationally that it is more beneficial for them to act alone than cooperate with their colleagues.

The study's unique contribution is the creation of a cooperation scale that can help us understand and analyze more deeply how MKs behave as rational actors and realize their ambitions. Our findings strengthen previous studies regarding co-sponsorship in a legislature never previously examined. Finally, this is the first study to look at parliamentary members in light of the strategic alliances they adopt based on legislation. The study opens up a new avenue for the future study of all kinds of cooperation strategies that exist in a wide variety of legislatures. Such investigations can look for similarities in the cooperation strategies as we found in this research or expand the explanations for the cooperation strategies we found.

\section{References}

Akirav, O. (2013). Re-election: Different Skills for Different Roles. Government and Opposition, 1-29.

Akirav, O. (2014). Catch-22: Arab Members of the Israeli Parliament. Representation, 1 December, 1-24. https://doi.org/10.1080/00344893.2014.982692

Aldrich, J. H. (1995). Why Parties? The Origin and Transformation of Political Parties in America. Chicago: University of Chicago Press. https://doi.org/10.7208/chicago/9780226012773.001.0001

Aleman, E., Calvo, E., Jones, M. P., \& Kaplan, N. (2009). Comparing co-sponsorship and Roll-Call Ideal Points. Legislative Studies Quarterly, 4(1), 87-116. https://doi.org/10.3162/036298009787500358

Anderson, W., Box-Steffensmeier, J., \& Sinclair-Chapman, V. (2003). The Key of Legislative Success in the U.S. House of Representatives. Legislative Studies Quarterly, 28(3), 357-386. https://doi.org/10.3162/036298003X200926

Arnold, R. D. (1990). The Logic of Congressional Action. New Haven: Yale University Press.

Axelrod, R. M., \& Hamilton, W. D. (1981). The Evolution of Cooperation. Science, 211, 1390-1396. https://doi.org/10.1126/science.7466396

Axelrod, R. M., \& Dion, D. (1988). The Further Evolution of Cooperation. Science, 242, 1385-1390. https://doi.org/10.1126/science.242.4884.1385

Axelrod, R. M. (1984). The Evolution of Cooperation. Basic Books, New York, US.

Blomgren, M., \& Rozenberg, O. (Eds) (2012). Parliamentary Roles in Modern Legislatures. Abingdon: Routledge.

Borchert, J. (2011). Individual Ambition and Institutional Opportunity: A Conceptual Approach to Political Careers in Multi-level Systems. Regional and Federal Studies, 21(2), 117-140. https://doi.org/10.1080/13597566.2011.529757

Bowler, S., Farrell, D. M., \& Katz, R. S. (1999). Party Cohesion, Party Discipline, and Parliaments. In Bowler, S. Farrell, D.M. \& Katz, R.S (Eds), Party Discipline and Parliamentary Government, Ohio State University Press. 3-22.

Bratton, K. A., \& Haynia, K. L. (1999). Agenda Setting and Legislative Success in State Legislatures: The Effect of Gender and Race. Journal of Politics, 61(3), 658-679. https://doi.org/10.2307/2647822

Briatte, F. (2016). Network Patterns of Collaboration in Twenty Parliaments. Network Science, 4(2), 266-271. https://doi.org/10.1017/nws.2015.31

Campbell, J. E. (1982). Co-sponsoring legislation in the US Congress. Legislative Studies Quarterly, 7, 415-422. https://doi.org/10.2307/439366

Chaudburi, A., Sopher, B., \& Strand, P. (2002). Cooperation in Social Dilemmas, Trust and Reciprocity. Journal of Economic Psychology, 23(2), 231-249. https://doi.org/10.1016/S0167-4870(02)00065-X

Cobb, M. D. \& Jenkins, J. A. (2001). Race and the representation of Blacks' interests during reconstruction. Political Research Quarterly, 54,181-204. https://doi.org/10.1177/106591290105400110

Cox, G. W., \& Terry, W. C. (2008). Legislative Productivity in the 93d-105th Congresses. Legislative Studies Quarterly, 33(4), 603-618. https://doi.org/10.3162/036298008786403123

Cox, G. W., \& Magar, E. (1999). How much is Majority Status in the U.S Congress Worth? American Political Science Review, 93(2), 299-309. https://doi.org/10.2307/2585397

Cox, G. W., \& McCubbins, M. D. (2005). Setting the Agenda, Cambridge: Cambridge University Press. https://doi.org/10.1017/CBO9780511791123

Crisp, B. F., Kanthak, K., \& Leijonhufvud, J. (2004). The Reputations Legislators Build: With Whom Should 
Representatives Collaborate. American Political Science Review, 98, 703-716. https://doi.org/10.1017/S0003055404041437

Evans, C. L., \& Oleszek, W. J. (2002). Massage Politics and Senate Procedure. In Campbell, C.C. \& Rae, N.C. (Eds). The Contentious Senate: Partisanship, ideology and the Myth of Cool Judgment. (pp. 107-127). New York: Rowman and Littlefield.

Fenno, R. F. (1973). Congressmen in Committees. Boston, MA: Little Brown.

Fenno, R. F. (1978). Home style: House members in their districts. Boston, MA: Little Brown.

Fowler, J. H. (2006a). Connecting the Congress: A Study of co-sponsorship Networks. Political Analysis, 14, $456-487$. https://doi.org/10.1093/pan/mpl002

Fowler, J. H. (2006b). Legislative co-sponsoring Networks is the US House and Senate. Social Networks, 28, 454-465. https://doi.org/10.1016/j.socnet.2005.11.003

Francis, W. L., \& Lawrence, W. K. (1996). Position Shifting in Pursuit of Higher Office. American Journal of Political Science, 40, 768-786. https://doi.org/10.2307/2111794

Frantzich, S. (1979). Who Makes Our Laws? The Legislative Effectiveness of Members of the U.S. Congress. Legislative Studies Quarterly, 4, 409-428. https://doi.org/10.2307/439582

Garand, J. C., \& Burke, K. M. (2006). Legislative Activity and the 1994 Republican Takeover: Exploring Changing Patterns of Sponsorship and co-sponsorship in the U.S. House. American Politics Research, 34, 159-188. https://doi.org/10.1177/1532673X05284415

Hamm, K. E., Harmel, R., \& Thompson, R. (1983). Ethnic and Partisan Minorities in Two Southern State Legislatures. Legislative Studies Quarterly, 8(2), 177-189. https://doi.org/10.2307/439427

Harbridge, L. (2010). The Elasticity of Partisanship in Congress: An Analysis of Legislative Bipartisanship. In Western Political Science Association 2010 Annual Meeting Paper.

Hasecke, E. B., \& Mycoff, J. D. (2007). Party Loyalty and Legislative Success: Are Loyalty Majority Party Members More Successful in the State House Representatives? Political Research Quarterly, 60(4), 607-617. https://doi.org/10.1177/1065912907305754

Hazan, R. Y. (Ed). (2006) Cohesion and Discipline in Legislatures: Political Parties, Party Leadership, Parliamentary Committees and Governance. London: Routledge.

Heidar, K., \& Koole, R. (2004). Parliamentary Party Groups in European Democracies Political Parties Behind Closed Doors. Taylor and Francis.

Hero, R. E., \& Tolbert, C. J. (1995). Latinos and substantive representation in the U.S. House of Representation: Direct, indirect, or nonexistent? American Journal of Political Science, 39, 640-652. https://doi.org/10.2307/2111648

Herrick, R., \& Moore, M. K. (1993). Political Ambition's Effect on Legislative Behavior: Schlesinger's Typology Reconsidered and Revisited. The Journal of Politics, 55(3), 765-776. https://doi.org/10.2307/2132000

Jenkins, J. A., Crespin, M. H., \& Carson, J. L. (2005). Parties as procedural coalitions in Congress: An Examination of Differing Career Tracks. Legislative Studies Quarterly, 30, 365-389. https://doi.org/10.3162/036298005X201590

Kessler, D., \& Krehbiel, K. (1996). Dynamics of co-sponsorship. American Political Science Review, 90, $555-566$. https://doi.org/10.2307/2082608

Kirkland , J. H., \& Gross, J. H. (2014). Measurement and Theory in Legislative Networks: The Evolving Topology of Congressional Collaboration. Social Networks, 36, 97-109. https://doi.org/10.1016/j.socnet.2012.11.001

Koger, G. (2003). Position Taking and co-sponsorship in the US House. Legislative Studies Quarterly, XXVII(2), 225-246. https://doi.org/10.3162/036298003X200872

Krehbiel, K. (1991). Information and Legislative Organization. Ann Arbor: University of Michigan Press. https://doi.org/10.3998/mpub.8850

Krehbiel, K. (1993). Where's the Party? British Journal of Political Science, 23, $235-266$. https://doi.org/10.1017/S0007123400009741

Krehbiel, K. (1999). The Party Effect From A to Z and Beyond. Journal of Politics, 61, 832-840. https://doi.org/10.2307/2647831

Louwerse, T., \& Otjes, S. (2015). The Impact of Parliamentary Specialization on co-sponsorship. Journal of Legislative Studies, 21(4), 476-494. https://doi.org/10.1080/13572334.2015.1076653 
Lublin, D. I. (1997). The Paradox of representation: Racial gerrymander and minority interests in Congress. Princeton, N.J: Princeton University Press.

Maestas, C. (2008). The Incentive to Listen: Progressive Ambition, Resources, and Opinion Monitoring Among State Legislators. The Journal of Politics, 65(2), 439-456.

Mansbridge, J. (1999). Should Black represent Blacks and women represent women? A contingent 'Yes'. Journal of Politics, 61, 628-657. https://doi.org/10.2307/2647821

Matthews, D. (1960). U.S Senators in Their World. New York: Random House.

Mayhew, D. R. (1974). Congress: The Electoral Connection. New Haven, CT: Yale University Press.

Mayhew, D. R. (2000). America's Congress. New Haven, CT: Yale University Press.

Maynard, S. J. (1982). Evolution and the Theory of Games Cambridge University press.

Meyer, K. (1980). Legislative Influence: Toward Theory Development Through Casual Analysis. Legislative Studies Quarterly, 5(4), 563-585. https://doi.org/10.2307/439574

Miquel, G. P., \& Snyder, J. M. (2006). Legislative Effectiveness and Legislative Careers. Legislative Studies Quarterly, XXXI(3), 347-381. https://doi.org/10.3162/036298006X201841

Moore, M. K., \& Thomas, S. (1991). Explaining Legislative Success in the U.S. Senate: The Role of the Majority and Minority Parties. Western Political Quarterly, 44, 959-970. https://doi.org/10.2307/448802

Morgenstern, S, Negri, J. J., \& Perez-Linan, A. (2008). Parliamentary Opposition in Non-Parliamentary Regimes: Latin America. The Journal of Legislative Studies, 12(1-2), 160-189. https://doi.org/10.1080/13572330801921166

Morris, J. S. (2001). Reexamining the Politics of Talk: Partisan Rhetoric in the $104^{\text {th }}$ House. Legislative Studies Quarterly, 26(1), 101-121. https://doi.org/10.2307/440405

Nowak, M. (2006). Five Rules for Evolution of Cooperation. Science, 8, 1560-1563. https://doi.org/10.1126/science.1133755

Olson, D. M. (1994). Democratic Legislative Institutions, New York: M.E. Sharpe, 132-144.

Ottolenghi, E. (2004). Choosing a prime minister: executive-legislative relations in Israel in the 1990s. The Journal of Legislative Studies, 10(2-3), 263-277. https://doi.org/10.1080/1357233042000322355

Ozbudun, E. (1970). Party Cohesion in Western Democracies: A Causal Analysis, Sage.

Parigi, P., \& Sartori, L. (2014). The Political Party as a network of cleavages: Disclosing the Inner Structure of Italian Political Parties in the Seventies. Social Networks, 36, 54-65. https://doi.org/10.1016/j.socnet.2012.07.005

Peress, M. (2013). Estimating proposal and status quo locations using voting and co-sponsorship data. The Journal of Politics, 75(3), 613-631. https://doi.org/10.1017/S0022381613000571

Rahat, G. (2007). Determinants of party cohesion: Evidence from the case of the Israeli parliament. Parliamentary Affairs, 60(2), 279-296. https://doi.org/10.1093/pa/gsm003

Rahat, G., \& Hazan, R. Y. (2005). Israel: The politics of an extreme electoral system. The Politics of Electoral Systems. Oxford University Press, Oxford, 333-351. https://doi.org/10.1093/0199257566.003.0016

Rocca, M. S. (2007). Nonlegislative Debate in the U.S House of Representatives. American Politics Research, 35(4), 489-505. https://doi.org/10.1177/1532673X07300233

Rocca, M. S., \& Gordon, S. B. (2010). The position-taking value of bill sponsorship in congress. Political Research Quarterly, 63(2), 387-397. https://doi.org/10.1177/1065912908330347

Rocca, M. S., \& Sanchez, G. R. (2008). The Effect of Race and Ethnicity on Bill Sponsorship and co-sponsorship in Congress. American Political Research, 36(1), 130-150. https://doi.org/10.1177/1532673X07306357

Rohde. D. (1979). Risk bearing and progressive ambition. American Journal of Political Science, 23, 1-26. https://doi.org/10.2307/2110769

Saalfeld, T. (2011). Parliamentary Questions as Instruments of Substantive Representation: Visible Minorities in the UK House of Commons, 2005-10. The Journal of Legislative Studies, 17(3), 271-289. https://doi.org/10.1080/13572334.2011.595121

Schiller, W. J. (1995). Senators as political entrepreneurs: Using bill sponsorship to shape legislative agenda. American Journal of Political Science, 39, 186-203. https://doi.org/10.2307/2111763

Schlesinger, J. A. (1966). Ambition and Politics. Political Careers in the United States. Chicago, IL: Rand McNally. 
Searing, D. D. (1994). Westminster's World: Understanding Political Roles. Cambridge, MA: Harvard University Press.

Smith, S. S., \& Gamm, G. (2001). The Dynamics of Party Government in Congress. In Dodd, L.C. \& Oppenheimer, B.I. (Eds). Congress Reconsidered, 7, 245-269. Washington DC: CQ Press.

Strom, K. (1997). Rules, reasons and routines: Legislative roles in parliamentary democracies. In: Muller, W.C. \& Saalfeld, T. (Eds) Members of Parliament in Western Europe: Roles and Behavior. London: Frank Cass, 155-174. https://doi.org/10.1080/13572339708420504

Sunnafrank, M., \& Ramirez, A. (2004). At First Sight: Persistent Relational Effects of Get-acquainted Conversations. Journal of Social and Personal Relationships, 21(3), 361-379. https://doi.org/10.1177/0265407504042837

Talbert, J. C., \& Potoski, M. (2002). Setting the legislative agenda: The dimensional structure of bill co-sponsoring and floor voting. Journal of Politics, 64, 864-891. https://doi.org/10.1111/0022-3816.00150

Tate, K. (2003). Black faces in the mirror: African American and their representatives in the U.S. Congress. Princeton, NJ:Princeton University Press.

Treul, S. A. (2009). Ambition and Party Loyalty in the U.S. Senate. American Politics Research, 37(3), 449-464. https://doi.org/10.1177/1532673X08322260

Victor, J. N. (2005). The Consequences of Ambition for Higher Office: Examining U.S. House Members Legislative Behavior, 1970-2004. Paper Presented at the Annual Meeting of the Midwest Political Science Association. Chicago, IL.

Wawro, G. (2000). Legislative Entrepreneurship in the U.S. House of Representatives. Ann Arbor: University of Michigan Press. https://doi.org/10.3998/mpub.16537

Weissert, C. S. (1991). Issue Salience and State Legislative Effectiveness. Legislative Studies Quarterly, 16(4), 509-520. https://doi.org/10.2307/440015

Wilson, R. K., \& Young, C. D. (1997). Co-sponsorship in the U.S. Congress. Legislative Studies Quarterly, 22, 25-43. https://doi.org/10.2307/440289

Wiseman, A. E., \& Wright, J. R. (2008). The Legislative Median and Partisan Policy. Journal of Theoretical Politics, 20(1), 5-30. https://doi.org/10.1177/0951629807084037

Woon, J. (2008). Bill Sponsorship in Congress: The Moderating effect of Agenda Positions on Legislative Proposals. The Journal of Politics, 70(1), 201-216. https://doi.org/10.1017/S0022381607080140

\section{Copyrights}

Copyright for this article is retained by the author(s), with first publication rights granted to the journal.

This is an open-access article distributed under the terms and conditions of the Creative Commons Attribution license which permits unrestricted use, distribution, and reproduction in any medium, provided the original work is properly cited. 